\title{
Dairy quality management promotes economic and environmental gains
}

\author{
Gestão da qualidade do leite promove ganhos econômicos e ambientais \\ La gestión de la calidad de la leche promueve las ganancias económicas y ambientales)
}

Received: 01/21/2021 | Reviewed: 01/24/2021 | Accept: 02/15/2021 | Published: 02/23/2021

Adriano Rogério Mendes
ORCID: https://orcid.org/0000-0002-5079-1977
Faculdade de Tecnologia e Ciências do Norte do Paraná, Brazil
E-mail: adriano_sumagro@ hotmail.com
Márcia Aparecida Andreazzi
ORCID: https://orcid.org/0000-0002-4663-3837
Universidade Cesumar, Brazil
E-mail: marcia.andreazzi@unicesumar.edu.br
Sandra Maria Simonelli
ORCID: https://orcid.org/0000-0001-8285-5296
Universidade Estadual de Londrina, Brazil
E-mail: sandra.simonelli. @uel.br
Fábio Luiz Bim Cavalieri
ORCID: https://orcid.org/0000-0003-4246-6995
Universidade Cesumar, Brazil
E-mail: fabio.cavalieri.@unicesumar.edu.br
Vinicius Eduardo Gargaro Silva
ORCID: https://orcid.org/0000-0002-8153-3559
Universidade Cesumar, Brazil
E-mail: vinicius.gargaro@gmail.com

\begin{abstract}
The world dairy cattle industry has advanced, but in Brazil, the quality of milk is a barrier to the strengthening of the chain. Thus, the objective of this research was to institute an action plan in ten dairy farms in the southern region of Brazil, which produced low quality milk, and to monitor changes in quality and economic gain, during one year. Critical points were identified and an action plan based on good agricultural practices and mastitis control was instituted. Monitoring consisted of collecting and analyzing milk samples for levels of fat, protein, somatic cell count and standard plate count. After twelve months, there was an increase $(\mathrm{p}<0.05)$ in the levels of fat and protein and a reduction $(p<0.05)$ in the somatic cell count and in the standard plaque count. The action plan improved the quality of milk and, therefore, reduced the disposal of milk in the environment, and increased the profitability of the properties studied.
\end{abstract}

Keywords: Milk production chain; Milk pricing; Dairy production; Economic and environmental sustainability.

\section{Resumo}

A pecuária leiteira mundial avançou, mas, no Brasil, a qualidade do leite é uma barreira para o fortalecimento da cadeia. Assim, o objetivo desta pesquisa foi instituir um plano de ação em dez fazendas leiteiras da região Sul do Brasil, que produziam leite de baixa qualidade, e monitorar as mudanças na qualidade e no ganho econômico, durante um ano. Pontos críticos foram identificados e um plano de ação baseado em boas práticas agrícolas e controle da mastite foi instituído. O monitoramento consistiu na coleta e análise de amostras de leite quanto aos níveis de gordura, proteína, contagem de células somáticas e contagem padrão em placas. Após doze meses, houve aumento $(\mathrm{p}<0,05)$ nos níveis de gordura e proteína do leite e redução $(\mathrm{p}<0,05)$ na contagem de células somáticas e na contagem padrão de placas. O plano de ação melhorou a qualidade do leite e, com isso, reduziu o descarte do leite no meio ambiente e aumentou a rentabilidade das propriedades estudadas.

Palavras-chave: Cadeia produtiva do leite; Precificação do leite; Produção de laticínios; Sustentabilidade econômica e ambiental.

\section{Resumen}

La producción lechera mundial ha avanzado, pero en Brasil, la calidad de la leche es una barrera para fortalecer la cadena. Así, el objetivo de esta investigación fue instituir un plan de acción en diez granjas lecheras en la región sur de Brasil, que producían leche de baja calidad, y monitorear los cambios en la calidad y la ganancia económica, durante un año. Se identificaron puntos críticos y se instituyó un plan de acción basado en buenas prácticas agrícolas y control de mastitis. El monitoreo consistió en recolectar y analizar muestras de leche en busca de grasa, proteína, 
recuento de células somáticas y recuento estándar en placa. Después de doce meses, hubo un aumento ( $<<0.05)$ en los niveles de grasa y proteína de la leche y una reducción $(\mathrm{p}<0.05)$ en el recuento de células somáticas y en el recuento estándar de placa. El plan de acción mejoró la calidad de la leche y, como resultado, redujo la eliminación de la leche al medio ambiente y aumentó la rentabilidad de las propiedades estudiadas.

Palabra clave: Cadena de producción de leche; Precios de la leche; Producción láctea; Sostenibilidad económica y ambiental.

\section{Introducion}

Dairy is one of the most important agricultural commodities in the world, being among the 5 most traded products, generating employment and income for approximately 1 billion people in the world (GDP, 2017). But in addition to its economic importance as a source of world income, milk is also a vital source of nutrition, as it is a source of calcium, proteins and vitamins (Siqueira et al., 2020).

In fact, milk is a considerable source of food energy, protein and fat in the world, contributing, on average, with 5\%, $10 \%$ and $9 \%$ of daily energy, protein and fat/per capita/day needs, respectively (GDP, 2017). It is noteworthy that the average world consumption of milk is $116.5 \mathrm{~kg} /$ inhabitant/ year (Hemme, 2018) and in Brazil, consumption is even greater, around 175 liters/inhabitant/year (Siqueira, 2019).

Dairy activity in Brazil, which is the 4th largest world producer of milk, contributes directly to the country's economy and follows a worldwide trend of increasing productivity based on the reduction in the number of producing farms, in the increase in the number of animals in production, in the sustainable development of dairy production and in the improvement of milk quality, seeking to offer a quality product for consumers and for the dairy industry (Milk Yearbook, 2019).

In Brazil, Normative Instruction $\mathrm{N}^{\circ} .76$ (IN76) established as quality parameters for chilled raw milk, the somatic cell count (SCC), the standard plate count (SPC), the analysis of centesimal composition and the research of residues of antibiotics (Brazil, 2018a) and defined the raw milk requirements, being: fat, minimum 3.0g/100g; proteins, minimum of $2.9 \mathrm{~g} / 100 \mathrm{~g}$, maximum SPC of 300.000 CFU.mL ${ }^{-1}$ and maximum SCC of 500.000 cells.mL ${ }^{-1}$ (Brazil, 2018a).

Among these quality requirements, SCC deserves mention. Somatic cells are a set of cells present in milk, derived from the desquamation of the mammary epithelium, milk secreting cells that are eliminated at the end of life, and defense cells of the animal's organism, macrophages, neutrophils and lymphocytes (Cespedes et al., 2014). However, certain situations can result in an increase in the quantity of these cells in milk, impairing their quality and yield in the dairy. An elevated SCC can be associated with several factors, such as intramammary inflammation, inadequate management on the farm, poor hygiene during milking and in the animals' environment (Quintão et al., 2017), mastitis (Langoni et al., 2017), poor dietary balance, stress, order of lactation (Cespedes et al., 2014) and room temperature (Vargas et al., 2014). Generally, a high SCC indicates that mastitis occurs and, in this situation, the consequences are a reduction in milk production and lower yield in the manufacture of dairy products (Belli et al., 2017).

Even with the IN76 and the high milk production in Brazil, it is emphasized that the quality of raw milk is still a major obstacle to the development and consolidation of the dairy industry in the country due to the high SCC, thus, actions for improving milk quality, based on minimal levels of somatic cells are needed.

To this end, Brazil published, in 2018, Normative Instruction $\mathrm{N}^{\circ} .77$, which establishes the criteria and procedures for the production, packaging, preservation, transport, selection and reception of raw milk and which also discusses Good Agricultural Practices (Brazil, 2018b), which, if properly used, can improve the quality of the milk produced. Furthermore, it is pointed out that improving the quality of milk also benefits the environment, since milk that is not suitable for human consumption and for industry becomes a residue on the properties and, in many cases, is discarded in the environment (Silano \& Santos 2016). 
Thus, based on the urgent need for balance in the production, economy and environment tripod, it appears that to strengthen the Brazilian dairy production chain, several actions must be promoted, involving the training of producers, the adoption of new technologies, greater technical assistance, as well as the implementation of milk payment programs according to their quality, which is already a common and successful practice in several countries. In view of the above, the objective of this research was to institute an action plan in ten dairy farms in the southern region of Brazil, which produced milk of inferior quality, proven by the high SCC, and to monitor changes in milk quality and economic gain, during one year, seeking to favor the economic, social and environmental sustainability of this production chain.

\section{Methodology}

\subsection{Place}

This qualitative and quantitative research, was carried out with data collected from ten dairy farms located in a dairy basin in southern Brazil, for twelve months. The definition of duration was based on the fact that the average milk production per cow, during one year, is indicative of the development of dairy activity and can indicate the degree of specialization of the farm and, when compared to different regions or periods, reflects the evolution or changes that occurred (Milk Yearbook, 2019).

The inclusion criteria for the properties and animals were: to have a crossbred Jersolando herd (1/2 Jersey blood and $1 / 2$ Holstein blood), to be a farm with an average production of 500L/day, to perform 2 daily milking, to have primiparous and multiparous cows in lactation, to use a system of extensive breeding and, mainly, have SCC above 500x1000 cell. $\mathrm{mL}^{-1}$ and SPC above 300.000 CFU.mL ${ }^{-1}$, according to Brazilian regulations.

Similar nutritional management was also prioritized, with the use of a rotational system, and with pasture, mainly of Panicum maximum, cultivating Mombasa and supply of concentrate, based on soybean meal, ground corn and mineral and vitamin core and water offered at will. The zoosanitary calendar for all properties followed the same schedule. Permission was requested for the institution of the action plan and for the collection of data to the owners who, after the agreement, signed the Free and Informed Consent Form.

\subsection{Collection and analysis of milk samples}

Both the collection of samples for diagnosis and inclusion of properties, as well as for monitoring the results of actions to reduce SCC and SPC, over a year, followed the methodologies described below.

The diagnosis for the inclusion of the properties was carried out in August 2017 and the data were collected for a period of 12 months, between the months of September 2017 and August 2018. The milk collection procedure in all properties followed the sequence: test for clinical mastitis detection, using the first milk jets; pre-disinfection (pre-dipping) of the ceilings with $0.3 \%$ glycerin iodine solution; drying the ceilings with paper towels and then mechanical milking was performed. Postdipping was performed by immersing the ceilings in a disinfectant solution containing $12 \%$ lactic acid.

For the evaluation of SCC, SPC, total protein and fat in milk, samples were collected in the expansion tank, monthly, for 12 months.

For SCC, total protein and fat in milk, the samples were collected in $50 \mathrm{~mL}$ plastic containers, containing $10 \mathrm{mg}$ of the Brononata $^{\oplus}$ preservative, previously identified with the date of collection and the number referring to the registration of the producer in the Paranaense Association of Cattle Breeders of the Holstein Breed (PACBHB). After shaking the samples, they were packed in cardboard boxes, and sent for analysis at the official laboratory of the Brazilian Network of Milk Quality Control Laboratories (MQCL), at the centralized milk analysis laboratory of the Herd Analysis Program Paraná Dairy (HAPPD) of PACBHB. The electronic counting of somatic cells in milk samples was performed using the flow cytometry 
method, with the Somacount 300® equipment (BENTLEY-1994) and expressed in cells.mL $\mathrm{mL}^{-1}$. To analyze the levels of total protein and fat in milk, the Bentley 2000 fast infrared analyzer (Barbano \& Clark, 1989) technique was used, expressed in $\mathrm{g} / 100 \mathrm{~g}$.

For the evaluation of the milk SPC, the samples were placed in sterile $50 \mathrm{~mL}$ plastic containers, containing $10 \mathrm{mg}$ of the bacteriostatic agent Azidiol, previously identified with the date of collection and number referring to the registration of the producer at PACBHB. After shaking the samples, they were packed in isothermal boxes with recyclable ice, and sent to the same laboratory.

\subsection{Action plan}

\subsubsection{Protocol of actions to reduce SCC and SPC}

\subsubsection{Identification of animals positive to the California Mastitis Test (CMT)}

After the identification and inclusion of the properties in the study, all animals from all properties were submitted to the California Mastitis Test (CMT). To perform the CMT, a racket containing four wells and the CMT reagent were used, where the milk was mixed with the reagent, homogenized and read after 10 seconds. According to the amount of somatic cells in the milk, a gel of varying thickness is formed. If the number of somatic cells is low, it does not form a gel and the result is negative, but if it forms a gel, the result is positive. The result is given in scores, according to the thickness of the gel, ranging from strokes - (slight gel formation) to + (weakly positive), ++ (positive reaction) and +++ (strongly positive reaction) (Embrapa, 2018).

\subsubsection{Culture and antibiogram of CMT positive animals}

After the identification of CMT-positive animals, milk samples were collected and sent to identify the pathogen causing mastitis. The collections of milk samples were performed according to the procedures described in the "Collection guide for microbiological analysis of milk" (Qualileite, 2013) and were sent to the Microbiology laboratory of the Diagnostic Center in Veterinary Medicine (CDMV) of the North University Paraná (UNOPAR), in southern Brazil, for microbiological diagnosis.

\subsubsection{Treatment definition}

After identification of the causative agent, the appropriate treatment for each animal was defined.

\subsubsection{Identification of critical points or causes of deviation in properties}

At the same time that the treatment of mastitis in the animals was instituted, a diagnosis was made in order to detect the critical points or the causes of deviations in the properties.

To carry out the diagnosis of critical points, a checklist based on Good Agricultural Practices (Brazil, 2018b) was used, which made it possible to assess, in general, the functioning and hygiene conditions of milking equipment, handling in milking, control of the temperature of the milk in the tank, the structure and hygiene conditions of the waiting room, milking room and feeding room, pasture conditions, shading areas, quality of the food and water provided, among others.

\subsubsection{Definition and implementation of control plans}

After identifying the critical points in each property, an action plan to correct deviations was defined and implemented, based on Good Agricultural Practices (Brazil, 2018b), which included actions involving improvements in sanitary management, food management and storage of foods; in the handling of milking and post-milking; in the adequacy, 
maintenance and hygiene of the facilities, equipment and utensils for milk production, in the water quality; in the refrigeration and storage of milk; training and personal hygiene and health of workers; integrated pest control and waste management and treatment of waste and effluents, rational use and storage of chemicals, toxic agents and veterinary drugs, control of suppliers of agricultural and livestock inputs, adoption of rational management practices and animal welfare and the provision of technical material. The Systematic Control of Mastitis was also adopted (Brazil, 2018b).

With regard to handling in milking, producers received and adopted the following guidelines: a) maintenance and hygiene of milking equipment with chlorinated alkaline detergent (130ppm); acid detergent twice a week, according to the manufacturer's instructions; c) washing the milkers' hands at each batch milked with soap and water, followed by the use of chlorine-based antiseptic; d) testing the black-bottomed mug; e) washing ceilings with water only in case of a lot of dirt; f) predipping with chlorinated solution at 750ppm and drying the ceilings after 30 seconds with individual paper towels; g) carrying out post-dipping with a product based on lactic acid; h) establishment of a milking line in accordance with the SCC; i) milking newly hatched animals at the end and disinfecting the milking cluster with chlorine; j) supply of roughage immediately after milking; k) treatment of animals with mastitis by means of antibiotic therapy.

A protocol was also established as a treatment criterion for drying the animals, using anhydrous cephalonium-based intramammary antibiotic, selected based on the results of the antibiograms. The use of the Hipramastivac ${ }^{\circ}$ vaccine was associated with drying, specific for mastitis caused by Staphylococcus aureus and Escherichia coli.

\subsection{Monitoring}

In order to verify the efficiency of the action plan actions, the properties were monitored for a period of twelve months. For that, milk samples were collected and analyzed for levels of fat, protein, SCC and SPC, monthly. The milk produced during the study was delivered and marketed at Pic Nic/Leprino Foods Company, located in southern Brazil.

\subsection{Data analysis}

The data were tested for normality by the Shapiro Wilks test and for homogeneity of variances by the Bartlett test. The mixed model methodology was used considering the property as a random effect. The variables SCC and SPC were transformed into Log on base 10. An analysis of variance was performed with a later Tukey test. 5\% significance was considered for all analyzes.

\section{Results and Discussion}

The establishment of the action plan promoted significant differences $(p<0.05)$ in the levels of fat, protein, SCC and SPC in the samples analyzed as a function of time (Table 1). It is noteworthy that all variables improved with the actions, however, SCC and SPC stood out.

Regarding the fat content (Table 1; Figure 1), it is known that in Brazil, the minimum level of fat in raw milk is $3.0 \mathrm{~g} / 100 \mathrm{~g}$ (Brazil, 2018a), thus, it is observed that the average levels of fat in the analyzed milk samples met the legal requirements since the beginning of the study, but despite this fact, the observed increase is considered to be very beneficial, since the levels of fat constitute one of the main parameters that influences the performance in the industry.

Dairy quality payment programs are strategies of dairy companies to motivate producers to produce high quality milk (Botaro et al., 2013) and some studies have already demonstrated their effectiveness (Nightingale et al., 2008). Countries like New Zealand and Germany adopted plans to improve milk quality several years ago, with procedures that involved legislation, payment for quality and education and training actions for milkers (Milk Yearbook, 2019). 
Table 1. Average values and standard deviation of the levels of fat $(\mathrm{g} / 100 \mathrm{~g})$, protein $(\mathrm{g} / 100 \mathrm{~g}), \mathrm{SCC}\left(\mathrm{x} 1000 \mathrm{cel}^{\mathrm{m}} \mathrm{mL}^{-1}\right)$ and SPC (x1000 CFU.mL $\left.{ }^{-1}\right)$ in the milk samples analyzed, from herds dairy farmers in the southern region of Brazil, according to the quarter of institution of the action plan.

\begin{tabular}{c|c|c|c|c}
\hline $\begin{array}{c}\text { Period of } \\
\text { action plan }\end{array}$ & $\begin{array}{c}\text { Fat } \\
(\mathrm{g} / 100 \mathrm{~g})\end{array}$ & $\begin{array}{c}\text { Protein } \\
(\mathrm{g} / 100 \mathrm{~g})\end{array}$ & $\begin{array}{c}\text { SCC } \\
\left(\mathrm{x} 1000 \mathrm{cells} . \mathrm{mL}^{-1}\right)\end{array}$ & $\begin{array}{c}\text { SPC } \\
\left.\left(\mathrm{x} 1000 \mathrm{CFU}^{\mathrm{m}}\right) \mathrm{mL}^{-1}\right)\end{array}$ \\
\hline Initiation & $3.68 \pm 0.11 \mathrm{c}$ & $3.315 \pm 0.00 \mathrm{~b}$ & $2764.0 \pm 2567.3 \mathrm{a}$ & $2844.2 \pm 3115.78 \mathrm{a}$ \\
$1^{\mathrm{o}}$ quarter & $3.72 \pm 0.08 \mathrm{c}$ & $3.340 \pm 0.05 \mathrm{~b}$ & $2313.5 \pm 2112.1 \mathrm{a}$ & $821.61 \pm 430.07 \mathrm{~b}$ \\
$2^{\mathrm{o}}$ quarter & $3.81 \pm 0.08 \mathrm{~b}$ & $3.404 \pm 0.03 \mathrm{a}$ & $702.83 \pm 1078.4 \mathrm{~b}$ & $67.733 \pm 136.44 \mathrm{c}$ \\
$3^{\mathrm{o}}$ quarter & $3.87 \pm 0.05 \mathrm{a}$ & $3.421 \pm 0.02 \mathrm{a}$ & $258.53 \pm 84.1 \mathrm{bc}$ & $23.067 \pm 10.39 \mathrm{c}$ \\
$4^{\mathrm{o}}$ quarter & $3.92 \pm 0.03 \mathrm{a}$ & $3.423 \pm 0.03 \mathrm{a}$ & $227.73 \pm 73.0 \mathrm{c}$ & $16.833 \pm 5.91 \mathrm{c}$ \\
\hline
\end{tabular}

* Significant by the F test $(\mathrm{p}<0.01)$; Means followed by different letters, in the same column, differ by Tukey's test ( $\mathrm{p}<0.05)$. Source: Authors.

The payment for quality, although still insipient in Brazil, is being used by some companies, which reward producers both in terms of volume and quality of milk, mainly based on higher levels of fat and protein and lower SCC and SPC. For example, the Nestlé Company, since 2005, prices milk differently, based on indicators such as percentage of fat, protein, SCC and SPC (Nestlé, 2020). Likewise, Pic Nic/Leprino Foods Company, has implemented a milk payment program based on quantity and quality in southern Brazil, which values the quality of the milk supplied and rewards the positive results obtained in the dairy properties, since better quality milk generates gains for the industry (Pic Nic - Leprino Foods Company, 2019).

Figure 1. Average values of fat levels $(\mathrm{g} / 100 \mathrm{~g})$ in the milk samples analyzed, from dairy herds in the southern region of Brazil, according to the property and the quarter of institution of the action plan.

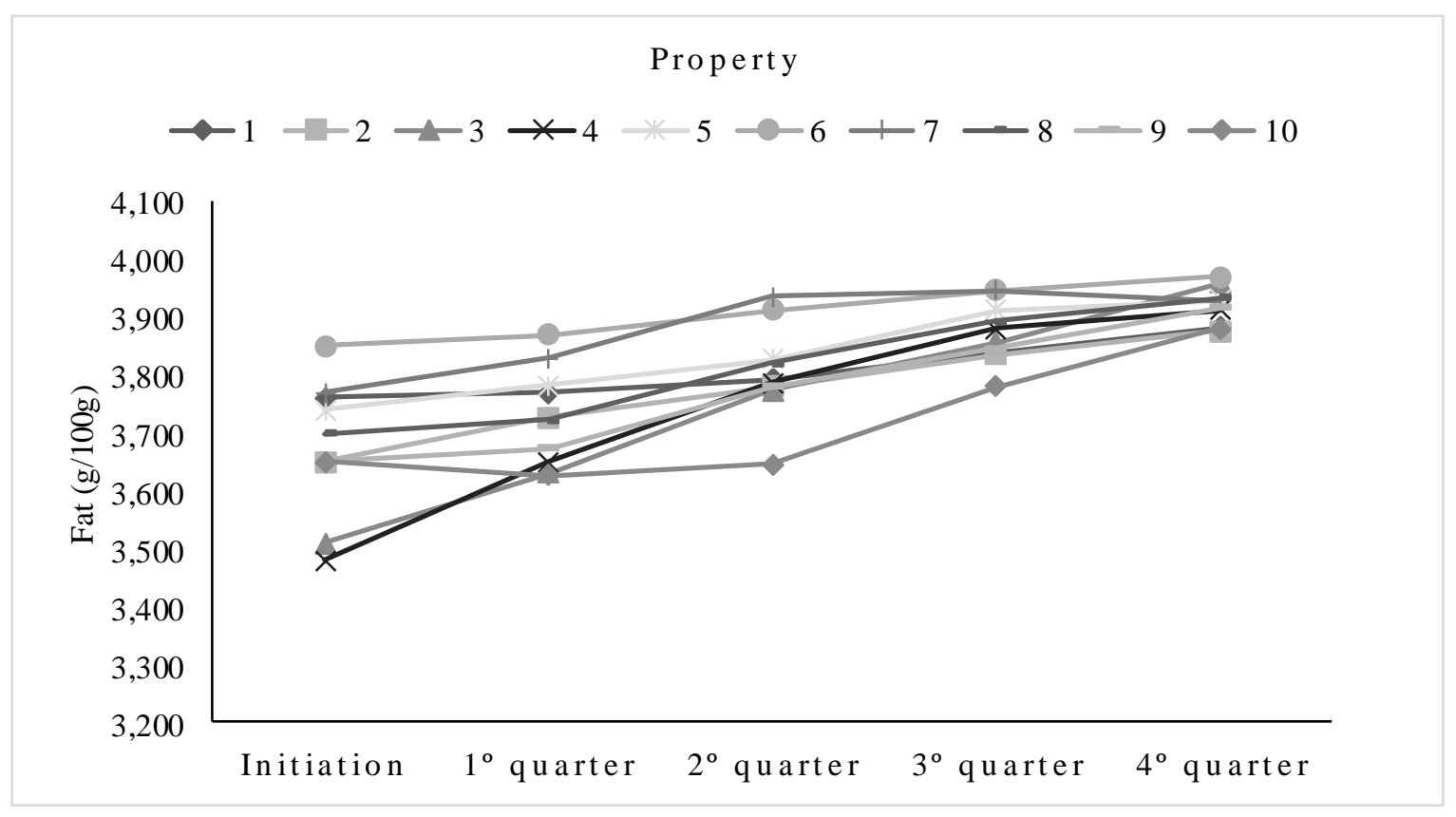

Source: Authors.

In this company, the percentage of fat is valued from $3.50 \%$, with the commercial value of milk fat of U\$ $1.77 / \mathrm{kg}$ as a reference. Thus, based on the values practiced by this company, the increase observed in the values of fat content from $3.68 \%$ to $3.92 \%$, referring to the beginning and 12 months of the institution of the action plan, reflected in an increase in the values subsidy paid to producers. Therefore, considering the average production of $500 \mathrm{~L}$ daily, these values represented a daily increase, due to the bonus, from U\$ 3.21 to U\$ 3.49 and monthly from U\$ 96.40 to U\$ 104.91 . 
The average percentage of proteins in milk was also found to be normal since the beginning of the study (Table 1; Figure 2), because according to Brazilian legislation, the minimum protein level in raw milk must be $2.9 \mathrm{~g} / 100 \mathrm{~g}$ (Brazil, 2018a). But, as seen in the fat level, the protein level increased after the start of the action plan, allowing an improvement in the yield of dairy products. Pic Nic - Leprino Foods Company, values protein from $3.1 \%$ for every $0.05 \%$ of gain. Thus, based on the initial average protein value of $3.31 \%$ and the increase after 12 months to $3.42 \%$, producers obtained an increasing appreciation in the liter of milk produced, resulting in an increase in the daily bonus of U\$2.27 to U\$ 3.31 and monthly from U\$ 68.05 to U\$ 99.24 .

Figure 2. Average values of protein levels $(\mathrm{g} / 100 \mathrm{~g})$ in the milk samples analyzed, originating from dairy herds in the southern region of Brazil, according to the property and the quarter of institution of the action plan.

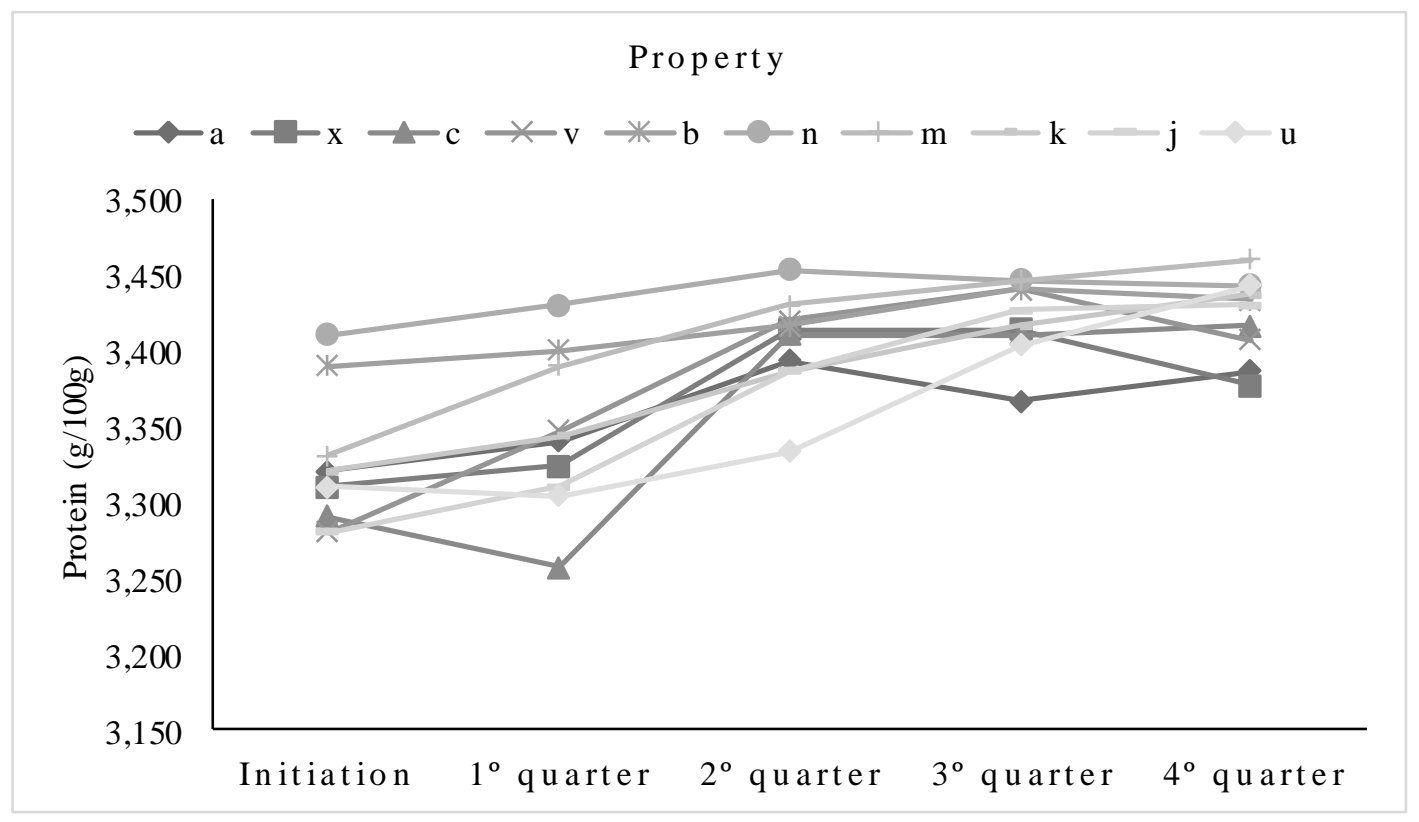

Source: Authors.

The average SCC value at the beginning of the study was 2.764 .000 cells. $\mathrm{mL}^{-1}$, after 6 months of the institution of the plan it reduced to 702.830 cells. $\mathrm{mL}^{-1}$ and at the end of 12 months, it showed a reduction of $91.20 \%$, reaching the value of 227.730 cells. $\mathrm{mL}^{-1}$ (Table 1; Figure 3). Considering that the Brazilian legislation recommends a maximum of 500.000 somatic cells.mL $L^{-1}$ (Brazil, 2018a), the positive result of the use of the action plan based on Good Agricultural Practices and on the Systematic Control of Mastitis, regarding the reduction at SCC and meeting Brazilian legal requirements.

The maximum accepted SCC values vary between countries, however, all countries adopt maximum values in order to preserve the quality and hygiene of milk. The United States of America and the Nordic countries adopt limits of a maximum of 250.000 cells.mL $\mathrm{mL}^{-1}$, the European Union, Argentina, Uruguay, New Zealand, Australia a maximum of $400.000 \mathrm{cells}^{\mathrm{m}} \mathrm{mL}^{-1}$, Brazil and Canada, a maximum of 500.000 cells. $\mathrm{mL}^{-1}$ and Chile 600.000 cells.mL $\mathrm{mL}^{-1}$ (Cespedes et al., 2014).

Somatic cells are constituted by the association of leukocytes and epithelial cells and are normally present in the milk of a healthy cow, however, in cases of inflammation or injury, the immune system increases these cells, therefore, these cells indicate, in addition to the quality of milk, some contagious infectious disease in the cow (Cespedes et al., 2014). Therefore, the data obtained reveal the positive effect of the actions implemented on the health of the studied herds. 
Figure 3. Average values of the SCC levels (x1000 cells. $\mathrm{mL}^{-1}$ ) in the milk samples analyzed, from dairy herds in the southern region of Brazil, according to the property and the quarter of institution of the action plan.

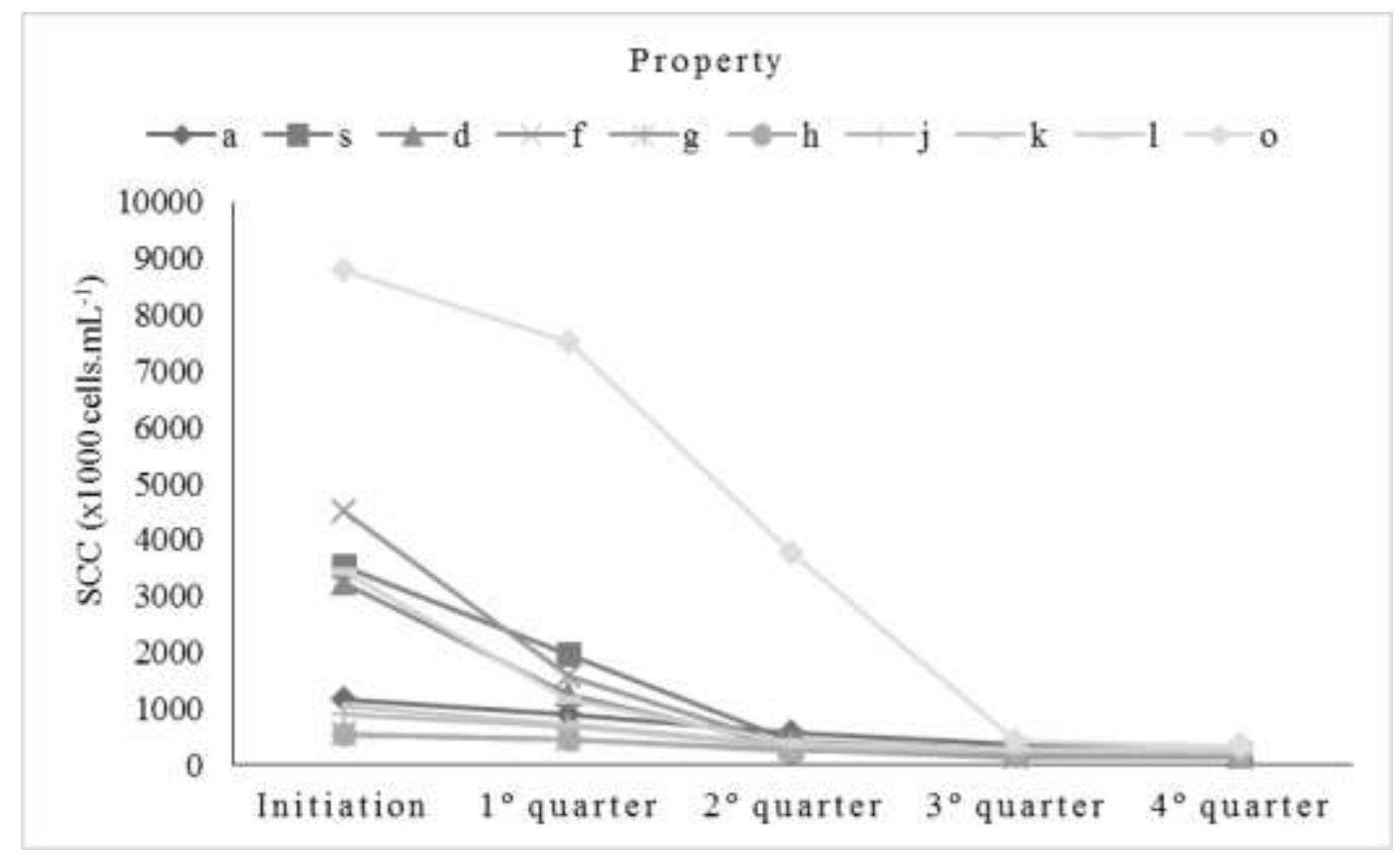

Source: Authors.

In fact, SCC is the most used indicator in mastitis control and prevention programs worldwide, and studies that evaluated the use of good milking practices reported a reduction in SCC (Lange et al., 2017). There are several negative points for dairy farming related to high SCC, among them, the reduction in milk production capacity, lower production per cow, reduction in the quality of milk and dairy products and worse yield in the industry, due to the lower fat and protein levels. Cespedes et al. (2014) reported that high SCC influences the processing, quality and flavor of dairy products, in addition to increasing the time for cheese production and increasing the loss of fat and protein in the whey, resulting in lower yield and shelf life of the products. Certainly, microbiological contamination directly interferes with the quality of milk and the production of its derivatives (Mattos et al., 2010; Lange et al., 2017; Gonçalves et al., 2018).

Silva et al. (2012) verified the influence of low, medium and high SCC and SPC values of raw milk on cheese yield and reported that high SCC is negatively correlated with cheese production. Mattiello et al. (2018) stated that the quality of milk directly influences the production of cheeses and that, when using milk with high SCC, the industry assumes the losses of lower yield and less efficient manufacturing of colonial cheeses. Lange et al. (2017) stated that despite the high volume of milk produced in Brazil, its quality is a problem for the dairy industry, especially with regard to SCC. The authors pointed out as critical points for the increase in SCC the type of milking, the way of drying the teats before milking, the protocol for the treatment of clinical mastitis, the training and hand hygiene of the milker.

Likewise, a study conducted on dairy farms, Quintão et al. (2017) showed that the SCC of chilled raw milk reflects the occurrence of mastitis in the herd and the management of the rural property. The authors found significant variations in the average milk SCC according to the time of year and listed other factors such as inadequate milking procedures, equipment hygiene and water quality. The authors stressed the importance of training milkers for milk production with low SCC and better quality.

The average SPC value revealed at the beginning of the survey was 2.844.200 CFU.mL ${ }^{-1}$ and, after 6 months, decreased by $97.62 \%$ (158.000 CFU.mL $\left.{ }^{-1}\right)$ and at 12 months, 99.93\%, reaching the mean values of $16.833 \mathrm{CFU}_{\mathrm{mL}}^{-1}$ (Table 1 ; Figure 4). Brazilian law recommends a maximum SPC value of 300.000 CFU.mL ${ }^{-1}$ as a requirement for raw milk (Brazil, 
2018a), therefore, it appears that after 6 months from the beginning of the study, the average result was much lower than required by Brazilian legislation, showing the efficiency of the action plan.

Figure 4. Average values of SPC levels $\left(x 1000 \mathrm{CFU} \cdot \mathrm{mL}^{-1}\right)$ in the analyzed milk samples, from dairy herds in the southern region of Brazil, according to the property and the quarter of institution of the action plan.

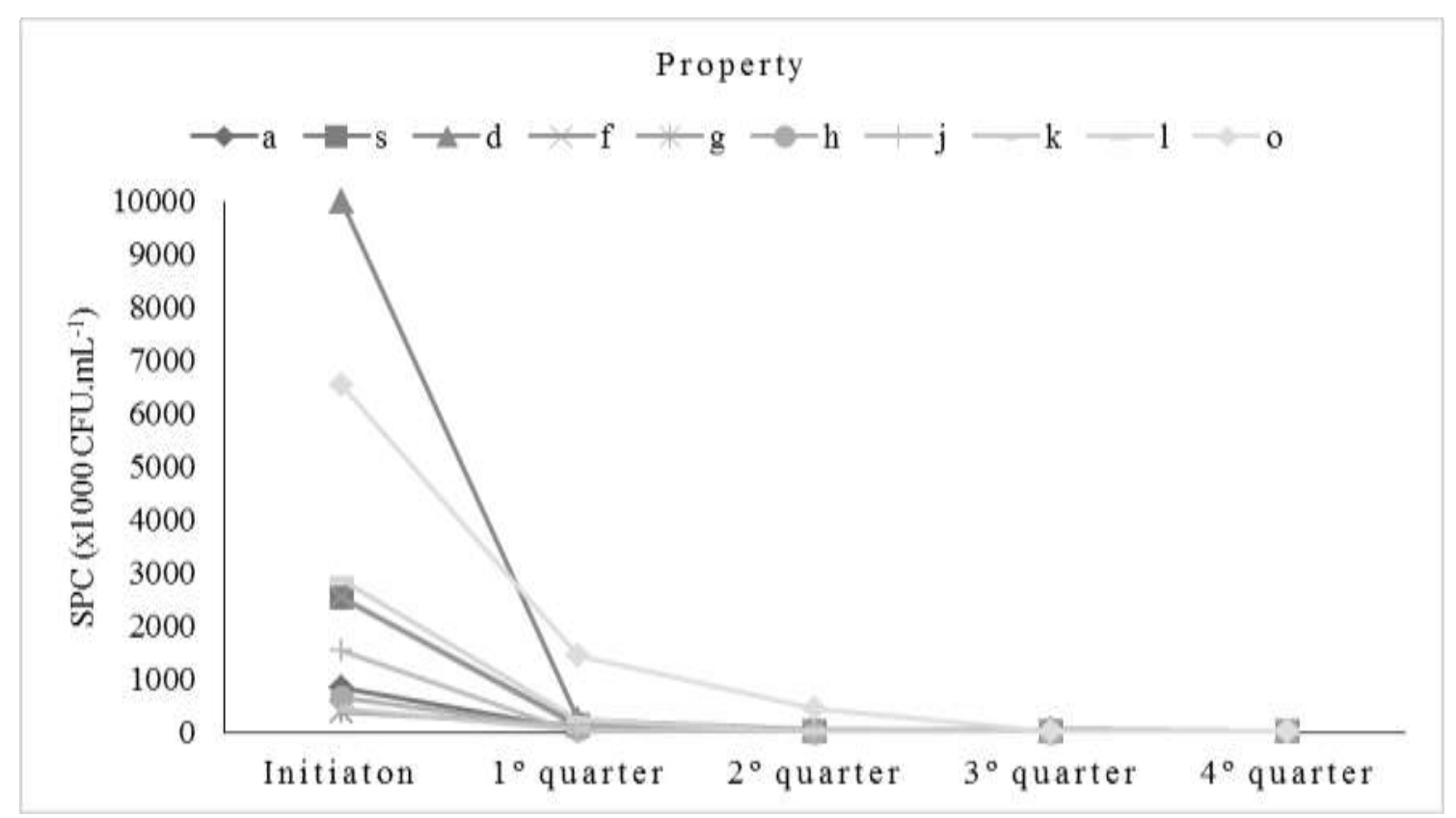

Source: Authors.

The SPC or total count of aerobic microorganisms is a test used to evaluate the microbiological quality of milk, including the hygiene standard of milk production and storage on the farm in order to guarantee the processing and obtaining of high quality products (Milk Yearbook, 2019). SPC is used in most developed countries and is considered a reliable indicator of the hygienic quality of milk.

For Pic Nic - Leprino Foods Company, the count below 300.000 is subsidized, while higher values will be penalized. Between 0 and 50.000 the bonus is greater, between 51.000 and 150.000 is intermediate, between 151.000 and 300.000 is less and for values greater than 301.000 there is no bonus. However, if the values persist for months, the producer will be penalized. Thus, the bonus in the payment of milk to producers from 6 months and 12 months after the implementation of the actions, considering the average production of 500L/day, was U\$ 9.45 per day and U\$ 283.55 monthly earnings.

In a work similar to this one, developed in five dairy farms in the southern region of Brazil, Bozo et al. (2013) sought to adapt the quality of chilled raw milk to the microbiological and SCC parameters established by state legislation. The authors reported that monitoring for seven months after the implantation of good milking practices and recommendations regarding the treatment of mastitis and the maintenance and hygiene of milking equipment, resulted in an average reduction of $93.4 \%$ in the SPC values and $74.3 \%$ at SCC. In addition, the authors also reported that adapting to the SPC and SCC standards generated an increase in monthly income, due to the payment for product quality.

The results of this study showed that the adoption of good practice and training actions aimed at improving the quality of milk, increased the economic return of producers, due to the bonuses. Twelve months after the start of the actions, the average levels of fat, protein, SCC and SPC reached resulted in values of U\$104.91, U\$ 99.24, U\$ 170.13 and U\$ 283.55, respectively, totaling $\mathrm{U} \$ 657,83$ in bonus payments related to the quality of the milk.

However, it is worth noting that, in addition to the lower yield in the dairy industry, other economic losses associated 
with high SCC and low milk quality are recognized, such as increased spending on medicines used in the treatment of animals, increased time of milking, increase in the disposal of cows in the herd (Cespedes et al., 2014), greater labor on the property and expenses with the technical work of a Veterinarian. In addition, there is also environmental damage due to the generation of a greater volume of waste milk, due to the use of anti-inflammatories and antibiotics that can be transferred to milk. Waste milk is a waste problem on the farm and cannot be disposed of in the environment (Silano \& Santos, 2016).

Therefore, in this context, concerns related to the economic and environmental sustainability of this production chain emerge, which stands out in the agricultural sector due to the importance it represents for the development of the country (Barbosa, 2008). The fundamental components for sustainable development are economic growth, protection of the environment and social equality, therefore, several actions must be developed in order to improve the performance indexes of the herds and the quality of the milk, associating the economic aspects, social and environmental.

Evidencing environmental concern, Nestlé launched, in 2018, the Good Practices on the Farm Nature Program, which, among several factors, values milk production without the use of hormones, employs animal welfare practices and mainly uses natural resources more rationally and employs environmental adequacy in relation to waste management (Nestlé, 2020).

Therefore, in order to guarantee the economic and environmental sustainability of the milk production chain, the search for production, with quantity and quality and with greater financial return for the producer and the better yield in the dairy industries must be associated with greater food security for humans and the lower environmental impacts, therefore, actions to control and monitor milk quality must be implemented in dairy properties, such as those that were the object of this study. In fact, specialized technical assistance, quality genetic material, the adoption of new technologies, the identification of critical points and the planning of intervention actions improve productivity, profitability and profitability (Vilela et al., 2016; Pires et al., 2018) and confer economic and environmental sustainability to the milk production chain.

\section{Conclusions}

The establishment of an action plan based on Good Agricultural Practices and Mastitis Control promoted significant differences in the levels of fat, protein, SCC and SPC, improving the quality of commercialized milk. Better quality has increased the price of milk paid to producers, depending on the bonuses received.

In addition to the direct gain with the increase in the value received per kilo of milk, the adoption of training and management adequacy actions reduced spending on medication, labor and decreased the disposal of animals and improper milk for consumption (disposal milk). Thus, the actions improved productivity and profitability and contributed to economic and environmental sustainability in dairy farms.

It is suggested that more actions and research be carried out in this area, involving a greater number of properties and animals of other breeds, in order to seek more and more the strengthening of the dairy cattle production chain.

\section{References}

Milk Yearbook. (2019). Anuário leite - Indicadores, tendências e oportunidades para quem vive no setor leiteiro. Texto Comunicação Corporativa - concessão Embrapa Gado de Leite.

Barbano, D. M. \& Clark, J. L. (1989). Infrared milk analysis - Challenges for the future. Journal of Dairy Science. 72:1627-1636.

Barbosa, GS (2008). O desafio do desenvolvimento sustentável. Revista Visões. 4(1):1-11.

Belli, C. Z. P., Cullmann, J. R., Ziech, M., Menezes, L. \& Kuss, F. (2017). Qualidade do leite cru refrigerado obtido em unidades produtivas no Sudoeste do Paraná. Revista de Ciências Agroveterinárias. 16: 109-120. <http://dx.doi.org/10.5965/223811711622017109>

Bozo, G. A., Alegro, L. C. A., Silva, L. C., Santana, E. H. W., Okano, W. \& Silva, L. C. C. (2013). Adequação da contagem de células somáticas e da contagem bacteriana total em leite cru refrigerado aos parâmetros da legislação. Brazilian Journal of Veterinary and Animal Science, 65(2):589-594. <http://dx.doi.org/10.1590/S0102-09352013000200040> 
Brazil. 2018a. Ministério da Agricultura, Pecuária e Abastecimento. Instrução Normativa $\mathrm{N}^{\circ} 76$, de 26 de novembro de 2018 . Aprova os Regulamentos Técnicos que fixam a identidade e as características de qualidade que devem apresentar o leite cru refrigerado, o leite pasteurizado e o leite pasteurizado tipo A.

Brazil. 2018b. Ministério da Agricultura, Pecuária e Abastecimento. Instrução Normativa $\mathrm{N}^{\mathrm{o}} 77$, de 26 de novembro de 2018 . Estabelece os critérios e procedimentos para a produção, acondicionamento, conservação, transporte, seleção e recepção do leite cru em estabelecimentos registrados no serviço de inspeção oficial.

Cespedes, C. O. C., Velho, J.W. S. \& Colombo, A. (2014). Interpretação da contagem das Células Somáticas em Propriedades Produtoras de Leite.

Embrapa - Empresa Brasileira De Pesquisa Agropecuária (2018). Agronegócio do leite - mastite. Texto Comunicação Corporativa - concessão Embrapa.

Gdp - Global Dairy Platform (2017). Annual Review. Rosemont, I. L. Texto Comunicação Corporativa - concessão Gdp.

Gonçalves, J. L., Kamphuis, C., Martins, C. M. M. R., Barreiro, J.R., Tomazi, T., Gameiro, A. H., \& Santos, M. V. (2018). Bovine subclinical mastitis reduces milk yield and economic return. Livestock Science. 210:25-32. <https://doi.org/10.1016/j.livsci.2018.01.016>

Hemme, T. (2018). IFCN Dairy report. Kiel, Germany: IFCN.

Lange, M. J., Zambom, M. A., Pozza, M. S. S., Simões, G. H., Fernandes, T., Tinini, R. C. R., Fornari, J. \& Anschau, F.A. (2017). Tipologia de manejo de ordenha: análise de fatores de risco para a mastite subclínica. Pesquisa Veterinária Brasileira. 37(11):1205-1212. <http://dx.doi.org/10.1590/s0100$736 \times 2017001100004>$

Langoni, H., Penachio D.S., Citadella, J. C. C., Laurino F., Faccioli-Martins, P. Y., Lucheis, S. B., Menozzi, B. D. \& Silva, A. V. (2011). Aspectos microbiológicos e de qualidade do leite bovino. Pesquisa Veterinária Brasileira. 31(12):1059-1065. <http://dx.doi.org/10.1590/S0100-736X2011001200004>

Langoni, H., Salina, A., Oliveira, G. C., Junqueira, N.B., Menozzi, B. D.; Joaquim, S. F. (2017). Considerações sobre o tratamento das mastites. Pesquisa Veterinária Brasileira. 37(11):1261-1269. <http://dx.doi.org/10.1590/s0100-736x2017001100011>

Mattos, M. R., Beloti, V., Tamanini, R., Magnani, D. F., Nero, L. A., Barros, M. A. F., Pires, E. M. F. \& Paquereau, B. P. D. (2010). Qualidade do leite cru produzido na região do agreste de Pernambuco, Brasil. Semina - Ciências Agrárias. 31(1):173-182. <http://dx.doi.org/10.5433/1679-0359.2010v31n1p173>

Nestlé (2018). Milk Producer Service. Texto Comunicação Corporativa - concessão Nestlé.

Pic Nic - Leprino Foods Company (2019). Programa de pagamento do leite por qualidade - PPQL. Circular técnica. 3p.

Pires, C. R. S., Costa, C. S., Melo, T. L. A., Teixeira, M. A. S. \& Carvalho, A. E. N. (2018). Sustentabilidade no sistema de produção de leite em pequenas propriedades rurais em Bragança-Pará. PubVet. 12(1):1-5.

Qualileite (2013). Guia de coleta para análise microbiológica. "Laboratório de Pesquisa em Qualileite do leite”.

Quintão, L. C., Cunha, A. F., Bragança, L. J., Coelho, K. S. N., Fonseca, M. S. \& Gouvêa, L. H. (2017). Evolution and factors influencing somatic cell count in raw milk from farms in Viçosa, state of Minas Gerais. Acta Scientiarum. Animal Sciences. 39(4):393-399. <http://dx.doi.org/10.4025/actascianimsci.v39i4.35364>

Silano, C. \& Santos, M. V. (2018). Leite de descarte: deve ser fornecido para bezerras?

Siqueira, K. B. (2019). O mercado consumidor de leite e derivados. Juiz de Fora: Embrapa Gado e Leite. Embrapa Gado de Leite. Circular Técnica, 120.

Siqueira, K. B., Binoti, M. L., Nunes, R. M., Borges, C. A. V., Pilati, A. F., Marcelino, G. W., Gama, M. A. S. \& Silva, P. H. F. (2020). Custo benefício dos nutrientes dos alimentos consumidos no Brasil. Ciência \& Saúde Coletiva, 25(3):1129-1135. <http://dx.doi.org/10.1590/1413-81232020253.11972018>

Vargas, D. P., Nörnberg, J. L., Mello, R. O., Sheibler, R. B., Breda, F. C. \& Milani, M. P. (2014). Correlações entre contagem de células somáticas e parâmetros físico-químicos e microbiológicos de qualidade do leite. Ciência Animal Brasileira. 15(4):473-483. <http://dx.doi.org/10.1590/18096891v15i420637>

Vilela, D., Ferreira, R. P., Fernandes, E. N., \& Juntolli, F. V. (2016). (Ed.). Pecuária de leite no Brasil: cenários e avanços tecnológicos. Brasília, DF: Embrapa, 127-144. 